\title{
PENYELESAIAN KASUS PELANGGARAN HAM BERAT MELALUI POLA REKONSILIASI PASCA PUTUSAN MAHKAMAH KONSTITUSI TAHUN 2006
}

\author{
SETTLEMENT OF CASES OF GROSS HUMAN RIGHTS VIOLATIONS \\ THROUGH POST-DECISION RECONCILIATION PATTERN OF 2006
}

\author{
Zahratul Ain Taufik \\ Magister Ilmu Hukum Universitas Mataram \\ email :zahratul.ain93@gmail.com \\ Naskah diterima : 07/07/2017; revisi : 25/07/2017; disetujui : 27/08/2017
}

\begin{abstract}
Indonesia is a country with a history of gross human rights violations. However, the case has not been resolved. In addition to court settlement, a reconciliation pattern is strongly recommended in the settlement of the case. But the rules of reconciliation has been cancelled by the Constitutional Court. This study aims to find patterns of solving gross human rights violations and analyze the arrangement of reconciliation in Indonesia post the Constitutional Court decision No. 006/PUU-IV 2006. The result of the research concludes that the settlement of cases of gross human rights violations is solved by Pattern of reconciliation with the establishment of an independent institution - Truth and reconciliation commissions-. In addition, the pattern of reconciliation can also be done in a familial way. Reconciliation arrangements exist in several regions of Indonesia, are Papua (Aceh and Palu. The patterns of reconciliation that exist in these rules vary, some of which use the pattern of truth and reconciliation commissions as well as some that use a pattern of familial reconciliation.
\end{abstract}

Keywords : Human Rights, Constitutional Court Decisions, Truth and Reconciliation Commissions

\section{Abstrak}

Indonesia adalah negara yang memiliki sejarah pelanggaran HAM berat. Namun, perkara tersebut belum terselesaikan. Selain penyelesaian melalui pengadilan, pola rekonsiliasi sangat dianjurkan dalam penyelesaian perkara dimaksud. Namun aturan tentang rekonsiliasi telah dibatalkan oleh Mahkamah Konstitusi. Penelitian ini bertujuan menemukan pola penyelesaian pelanggaran HAM berat serta menganalisis pengaturan rekonsiliasi di Indonesia pasca Putusan MK No. 006/PUUIV 2006. Hasil penelitian menyimpulkan bahwa Penyelesaian Kasus-kasus pelanggaran HAM berat diselesaikan dengan Pola rekonsiliasi dengan dibentuk Lembaga independen (KKR). Selain dengan itu, pola rekonsiliasi juga bisa dilakukan secara kekeluargaan. Pengaturan rekonsiliasi ada di beberapa daerah di Indonesia, yakni Papua, Aceh dan Palu Pola rekonsiliasi yang ada dalam aturan-aturan tersebut berfariasi, ada yang menggunakan pola KKR juga ada yang menggunakan pola rekonsiliasi kekeluargaan.

Kata kunci: HAM, , Putusan MK, KKR

\section{PENDAHULUAN}

Negara Indonesia merupakan negara yang menjunjung tinggi Hak Asasi Manusia. Pengakuan dan perlindungan atas hak-hak asasi manusia terbukti dengan adanya pengaturan mengenai pelangga- ran terhadap hak asasi manusia, yang diatur di dalam Kitab Undang-Undang Hukum Pidana (KUHP) dan pelanggaran HAM berat yang diatur di dalam UU No. 26 Tahun 2000 tentang Pengadilan HAM. Pelanggaran HAM berat pernah terjadi sebelum diundangkannya UU No. 26 tahun 
2000 tentang Pengadilan HAM, yaitu diantaranya ada Peristiwa Trisakti, Semanggi I (1998) dan Semanggi II (1999) yang disingkat kemudian menjadi TSS; Peristiwa Mei 1998; Penghilangan Orang Secara Paksa 1997-1998; Peristiwa Talangsari 1989; Peristiwa 1965; Peristiwa Penembakan Misterius. ${ }^{1}$

Dalam undang-undang tersebut diatur mengenai HAM berat dengan diberlakukannya asas retroaktif. Asas tersebut berarti bahwa hukum dapat berlaku surut. Sehingga konsekwensinya adalah setiap perbuatan pelanggaran yang dilakukan terhadap HAM dan dikategorikan sebagai kejahatan serta waktu kejadiannya sebelum diundangkannya undang-undang tersebut dapat diadili demi keadilan.

Situasi penegakan hukum HAM terhadap pelanggaran HAM berat masa lalu seringkali menemukan deadlock, terkunci dan hampir dipastikan tidak bisa dibuka kembali. ${ }^{2}$ Hal tersebut terbukti dari kegagalan-kegagalan proses penyelesaian pelanggaran HAM berat masa lalu. Seperti diantaranya, Peristiwa Trisakti, Semanggi I (1998) dan Semanggi II (1999) yang kemudian disingkat TSS, berdasarkan rekomendasi dari Komnas HAM bahwa ada dugaan pelanggaran HAM yang berat dan perlu adanya pembentukan Pengadilan HAM ad hoc. Namun statusnya, Komnas HAM menyerahkan hasil penyelidikan pada April 2002; dan Pada tahun 2008, Jaksa Agung menyatakan tidak dapat melanjutkan penyidikan karena sudah ada pengadilan militer dengan adanya putusan yang tetap; dengan begitu Komnas HAM tetap menyatakan perlu ada pengadilan HAM ad hoc. ${ }^{3}$

http://elsam.or.id/downloads/248204_ HASIL_ PENYELIDIKAN_KOMNAS_HAM_YANG_BELUM_ DITINDAKLANJUTI. pdf, diakses pada 10 april 2014, 23.08

${ }^{2}$ Eddy O.S. Hiariej, Asas Legalitas dan Penemuan Hukum dalam Hukum Pidana, Erlangga, Jakarta: 2009 Hlm. 213

${ }^{3}$ elsam.or.id, Loc.Cit
Kasus tersebut diambangkan begitu saja. Contoh kasus tersebut hanya sebagian kecil dari beberapa kasus pelanggaran HAM berat yang terjadi di masa lalu yang proses penyelesaiannya ada yang berhasil sampai pada pemeriksaan di sidang pengadilan, penyidikan oleh Jaksa Agung, bahan kajian DPR untuk pembentukan Pengadilan HAM ad hoc, bahkan ada yang hanya berhasil sampai pada hasil penyelidikan Komnas HAM saja.

Hal yang terurai diatas membuktikan bahwa proses penyelesaian perkara pelanggaran HAM berat di Indonesia belum bisa secara independen dan secara yudikatif ditangani, melainkan juga masih ada ikut campur dari pihak legislatif, bahkan eksekutif. Padahal diketahui bahwa proses peradilan yang independen adalah proses peradilan yang tanpa intervensi pihak lain. Proses peradilan tersebut kemudian dijadikan pelajaran agar kejahatan kemanusiaan tidak terjadi lagi dalam hidup dan kehidupan manusia ke depan.

Menurut penulis, perlu adanya proses penyelesaian non yudisial. Penyelesaian non yudisial sesungguhnya menjadi salah satu prosedur penyelesaian yang diamanatkan dalam UU No. 26 Tahun 2000 tentang Pengadilan HAM dalam Pasal 47.

Untuk menjalankan amanat dari pasal 47 dan Setelah menuai berbagai perdebatan panjang mengenai istilah dan penerbitan undang-undang tentang KKR, akhirnya pada tanggal 7 September 2004, DPR mengesahkan UU No. 27 Tahun 2004 tentang Komisi Kebenaran dan Rekonsliasi. ${ }^{4}$ Namun, belum genap dua tahun, KKR dibatalkan oleh Putusan Mahkamah Konstitusi dengan Putusannya Nomor 006/ PUU-IV/2006 tentang Pengujian UU No. 27 Tahun 2004 tentang Komisi Kebenaran dan Rekonsiliasi Tanggal 7 Desember 2006.

4 Antonius Sumarwan, Menyebrangi Sungai Air Mata: Kisah Tragis TAPOL'65 dan Upaya Rekonsiliasi, Kanisius, Yogyakarta: 2007, hlm. 216 
Pertimbangan Mahkamah Konstitusi dalam pembatalan undang-undang tersebut adalah diantaranya, asas dan tujuan KKR, sebagaimana termaktub dalam Pasal 2 dan Pasal 3 UU No. 27 Tahun 2004 tentang Komisi Kebenaran dan Rekonsiliasi tidak mungkin dapat diwujudkan karena tidak adanya jaminan kepastian hukum (rechtsonzekerheid). ${ }^{5}$

Dengan begitu, harapan para pegiat HAM untuk menuntaskan berbagai kasus tersebut melalui jalur diluar pengadilan (non yudisial) tidak memiliki landasan hukum yang kuat. Namun seperti yang telah disebutkan diatas, bahwa prosedur penyelesaian kasus-kasus pelanggaran HAM berat yang terjadi sebelum tahun 2000 dapat diselsaikan melalui jalur non yudisial.

Tidak adanya aturan yang mengatur mengenai prosedur penyelesaian kasuskasus pelanggaran HAM berat diluar pengadilan, maka terjadi kekosongan norma (vacum of norm). Berangkat dari kenyataan tersebut, maka tulisan ini difokuskan untuk menkaji bagaimana pola penyelesaian pelanggaran HAM berat pasca Putusan MK No. 006/PUU-IV Tahun 2006 tentang pengujian UU No. 27 tahun 2004 tentang KKR mengidentifikasi Bagaimana pengaturan rekonsiliasi yang dapat diterapkan dalam penyelesaian kasus pelanggaran HAM berat di Indonesia pasca Putusan MK No. 006/PUU-IV Tahun 2006 tentang pengujian UU No. 27 tahun 2004 tentang KKR

Penelitian ini menggunakan jenis penelitian hukum normatif (legal research), yakni suatu proses untuk menemukan suatu aturan hukum, prinsip-prinsip hukum, maupun doktrin-doktrin hukum untuk menjawab permasalahan hukum yang dihadapi. Untuk menemukan hal-hal

\footnotetext{
${ }^{5}$ Putusan Mahkamah Konstitusi Nomor 006/PUUIV/ 2006 tentang Undang-Undang Nomor 27 Tahun 2004 tentang komisi kebenaran dan rekonsiliasi Tanggal 7 desember 2006
}

tersebut, maka pendekatan masalah yang digunakan adalah Pendekatan Perundangundangan (statute approach), Pendekatan konseptual (conceptual approach), Pendekatan Sejarah (historycal approach), dan Pendekatan kasus (case approach).

Tekhnik pengumpulan bahan hukum yang digunakan adalah dengan melalui penelitian kepustakaan yang bersumber dari peraturan perundang-undangan, bukubuku, dokumen resmi, publikasi, dan hasil penelitian. ${ }^{6}$ Untuk menganalisis bahan hukum, penulis menggunakan metode penemuan hukum (rechtsvinding). Yakni dengan menggali hukum yang hidup di dalam masyarakat. Dengan berpatokan pada teori hukum mengenai "ratio hukum" dari hukum positif, sebagai salah satu usaha dalam mengisi kekosongan hukum, ${ }^{7}$ juga untuk pemecahan masalah hukum penulis menggunakan metode analisa deskriptif kualitatif terhadap data primer dan sekunder. Dari hasil analisis deskriptif tersebut maka penulis akan menarik kesimpulan yang diambil dengan menggunakan cara berpikir deduktif, yaitu dengan cara berpikir yang mendasar pada hal-hal yang bersifat umum kemudian ditarik kesimpulan secara khusus.

\section{PEMBAHASAN}

Pola Penyelesaian Pelanggaran Ham Berat Pasca Putusan MK Nomor 006/PUUIV Tahun 2006 Tentang Pengujian Terhadap Undang-Undang Nomor 27 Tahun 2004 Tentang Komisi Kebenaran Dan Rekonsiliasi

\section{a. Prinsip Dasar Hak Asasi Manusia}

Manusia (dalam konteksnya dengan pendekatan agama Islam) adalah makhluk yang paling sempurna yang diciptakan Allah SWT dengan segala pengetahuan

\footnotetext{
${ }^{6}$ Zainudin Ali, metode penelitian hukum, Cet. 1, Sinar Grafika, Jakarta, 2009, Hlm. 107

${ }^{7}$ Suratman, \& Philips Dillah, Metode Penelitian Hukum, Alfabeta: Bandung, 2013, Hlm. 84
} 
yang diberikan Allah manusia memperoleh kedudukannya yang paling tinggi dibandingkan dengan mahluk lainnya. ${ }^{8} \mathrm{Hak}$ asasi merupakan hak yang wajib dilindungi dan dijunjung tinggi dalam berkehidupan di dunia.

Hak Asasi Manusia merupakan tatanan pergaulan global sebagai wujud dari pelembagaan kebebasan agar setiap orang dapat menggunakan seluruh potensi manusiawinya secara maksimal. ${ }^{9}$ Selanjutnya Hesti Armiwulan Sochmawardiah menjelaskan bahwa penghargaan dan penghormatan HAM dijiwai dengan sistem idea yang memandang manusia dalam kedudukan harkat dan martabat serta derajatnya yang tinggi. ${ }^{10}$

Hak asasi merupakan hak yang wajib dilindungi dan dijunjung tinggi dalam kehidupan berbangsa dan bernegara. Karena menurut Mien Rukmini, HAM adalah hak yang melekat pada jati diri manusia secara kodrati dan universal berfungsi menjaga integritas keberadaan manusia sebagai karunia Tuhan Yang Maha Esa yang tidak boleh diabaikan dan dirampas oleh siapapun juga. ${ }^{11}$

Pengaturan komisi negara dalam UUD NRI 1945 digagas dalam rangka penguatan prinsip negara hukum yang tertuang pada pasal 2 ayat (1) UUD NRI 1945. Keberadaan komisi negara untuk mendorong dan menjaga 1). Sistem peradilan yang independen dan berintegritas, bersih dari mafia peradilan maka komisi yudisial diatur dalam bab tersendiri keluar dari pasal 24 UUD NRI 1945. 2). Perlindungan HAM maka diakomodir Komnas HAM, 3). Pemilihan umum dibentuk KPU dalam bab tersendiri, dan terciptanya pemerintahan

\footnotetext{
${ }^{8}$ Al-Qur'an, Surat Al-Baqarah ayat 33

${ }^{9}$ Hesti Armiwulan Sochmawardiah, Op.Cit. Hlm. 37

${ }^{10} \mathrm{Ibid}$

${ }^{11}$ Mien Rukmini, Perlindungan HAM melaui Asas Praduga Tidak bersalah dan Asas Persamaan Kedudukan di Depan Hukum pada Sistem Peradilan Pidana Indoesia, Ed. 1, Cet.1, Alumni, Bandung, 2003, hlm.Pengantar vii
}

yang baik dan bersih maka dibentuklah KPK. ${ }^{12}$

\section{b. Pengaturan Pelanggaran HAM Be- rat}

1) Pengaturan HAM Berat dalam Statuta Roma

Di dalam Statuta Roma (1998) Pelanggaran HAM berat secara eksplisit tidak disebutkan, namun ada padanannya dengan yang dikenal pada Konvensi Jenewa (1949) tetapi dengan istilah lain yang disebut adalah kejahatan paling serius, sepertiyangdisebutkandalamPasal 1 Statuta Roma mengenai Mahkamah.

Jurisdiksi Mahkamah Pidana Internaional terbatas pada kejahatan paling serius yang menyangkut masyarakat internasional secara keseluruhan. Mahkamah mempunyai jurisdiksisesuaidenganStatutaberkenaan dengan kejahatan-kejahatan berikut: (a) Kejahatan genosida; (b) Kejahatan terhadap kemanusiaan; (c) Kejahatan perang; (d) Kejahatan agresi. Disebutkan pada Pasal 5 mengenai Kejahatan yang Termasuk dalam Jurisdiksi Mahkamah Pidana Internasional (Crimes within the Jurisdiction of the Court).

2) Pengaturan Pelanggaran HAM Berat di Indonesia

Pelanggaran HAM diatur dalam peraturan perundang-undangan dan konstitusi negara Indonesia, bukan hanya terkait pelanggaran yang akan terjadi, melainkan juga terhadap pelanggranpelanggaran yang telah terjadi sebelum diundangkannya undang-undang tersebut adalah UU No. 26 Tahun 2000 tentang Pengadilan HAM.

\footnotetext{
${ }^{12}$ Muh Risnain dan Sri Karyati, Menimbang Gagasan Perubahan Konstitusi dan Tata Cara Perubahan Konstitusi Republik Indonesia 1945, Jurnal Ius (Kajan Hukum dan Keadilan) Volume 5 No. 1 2017, hlm 115.
} 
Zahratul Ain Taufik | Penyelesaian Kasus Pelanggaran Ham Berat Melalui Pola Rekonsiliasi Pasca Putusan.....

Undang-undang tersebutmeratifikasi sebagian dari Statuta Roma yang menjadi peraturan internasional mengenai pelanggaran HAM. Pengaturan mengenai pelanggaran HAM Berat di Indonesia tertuang dalam Pasal 7 UU No. 26 Tahun 2000 tentang Pengadilan Hak Asasi Manusia yakni, kejahatan genosida dan kejahatan terhadap kemanusian.

\section{c. Penyelesaian Pelanggaran HAM Be- rat di Indonesia}

1) Penyelesaian Melalui Pengadilan

Mekanisme penyelesaian melalui pengadilan atau litigasi adalah suatu mekanisme penyelesaian perkara HAM berat melalui pengadilan. ${ }^{13}$ Pembentukan pengadilanHAMdiIndonesiamerupakan pelaksanaandariamanatUUNo.39Tahun 1999 tentang HAM, yakni termuat dalam Pasal 104 ayat (2), maka diundangkan UU No. 26 Tahun 2000 dan ditetapkan pada tanggal 23 November tahun 2000 tentang Pengadilan HAM.

Di samping itu, Indonesia adalah negara hukum. ${ }^{14}$ Menurut Jimly Asshidiqie, terdapat dua belas prinsip pokok negara hukum (rechtstaat). ${ }^{15}$ Lebih lanjut beliau menyatakan bahwa kedua belas prinsip pokok tersebut merupakan fundamental utama sebagai penyangga untuk berdiri tegaknya suatu negara modern sehingga dapat disebut sebagai negarahukumdalamartiyangsebenarnya, salah satu prinsip tersebut adalah adanya peradilan HAM. ${ }^{16}$

Kewenangan absolut dari pengadilan HAM ini adalah kejahatan genosida dan kejahatanterhadapkemanusiaan.Hukum

\footnotetext{
${ }^{13}$ Suparman Marzuki, Op.Cit, hlm. 62

${ }^{14}$ Indonesia, Undang-Undang Dasar Tahun 1945, Pasal 1 ayat (3)

${ }^{15}$ Jimly Asshidiqie, dalam I Dewa Made Putra Wijaya, Mengukur Derajat Demokrasi Undang-Undang No. 42 Tahun 2008 tetangg Pemilu Presiden dan Wakil Presiden,Jurnal IUS, Vol. 2, No. 6, Desember 2014 , Hlm.560

${ }^{16} \mathrm{Ibid}$
}

acara yang digunakan pada pengadilan HAMadalahhukumacarayangditentukan dalam UU No. 26 Tahun 2000 tentang Pengadilan HAM. Mekanisme hukum acara dalam UU No. 26 Tahun 2000 tentang Pengadilan HAM tidak berbeda dari mekanisme yang digunakan dalam penyelesaian pelanggaran HAM di atur dalam KUHP melalui hukum acara yang tertuang dalam KUHAP, dimulai dari penyelidikan, penyidikan, penuntutan dansidangdipengadilansertapelaksanaan putusan pengadilan. Yang berbeda, adalah instansi yang berwenang melakukan penyelidikan, penyidikan, penuntutan serta pengadilan yang mengadili.

Penyelidikan pelanggaran HAMBerat dilakukanolehKomisiNasionalHak Asasi Manusia (Komnas HAM). Penyidikan perkara pelanggaran hak asasi manusia yang berat dilakukan oleh Jaksa Agung. Penuntutan perkara pelanggaran hak asasi manusia yang berat dilakukan oleh Jaksa Agung. Pemeriksaan di sidang pengadilan terkait pelangaran HAM berat dilakukan di Pengadilan HAM.

Pengadilan HAM tingkat pertama sebagaimana yang tertuang dalam Pasal 2 UUNo.26Tahun2000tentangPengadilan HAM, berada di lingkungan peradilan umum. Namun sejak undang-undang ini diundangkan sampai sekarang baru ada empat pengadilan HAM yang dibentuk, yangketentuannyaberadapadaketentuan peralihan Pasal 45 UU No. 26 Tahun 2000 tentang Pengadilan HAM. Pengadilan HAM tersebut berpada pada Pengadilan Negeri Jakarta Pusat; Pengadilan Negeri Surabaya; Pengadilan Negeri Medan; dan Pengadilan Negeri Makassar.

2) Mekanisme di Luar Pengadilan

Paradigma dalam hukum pidana bersifat retributif, seperti halnya yang dianut Het Wetboek van Starfrecht voor Indonesia (KUHP), dimana hukum harus mengakibatkan pada si penjahat 
kerugian atau penderitaan paling tidak seimbang dengan apa yang dialami si korban. ${ }^{17}$ Hal ini secara filosofis kadangkadang tidak memuaskan semua pihak, oleh karena itu perlu adanya pemikiran penyelesaian perkara di luar pengadilan (out court system) dengan maksud agar dapat menyelesaikan konflik yang terjadi antara pelaku dengan korban. ${ }^{18}$

Mekanisme penyelesaian perkara di luarpengadilanadalahsalahsatualternatif yang digunakan oleh sebagian besar masyarakat, bukan hanya masyarakat Indonesia, melainkan juga masyarakat dunia. ${ }^{19}$ Dalam ranah hukum pidana, penyelesaian sengketa di luar pengadilan dikenal dengan istilah Mediasi Penal. Penyelesaian di luar pengadilan atau mediasi penal ini merupakan suatu upaya dalam melakukan pembaharuan hukum pidana (penal reform). Pembaharuan hukum pidana (penal reform) menurut Barda Nawawi Arief, pada hakikatnya termasuk bidang penal policy yang merupakan bagian dan terkaiterat dengan law enforcment policy, criminal policy dan social policy. ${ }^{20}$

Ide dan Prinsip Kerja Mediasi Penal adalah Pertama, Penanganan konflik (Conflict Handling/ Konfliktbearbeitung); kedua, Berorientasi pada proses (Process Orientation-Prozessorientierung); ketiga, Proses informal (Informal Proceeding - Informalität); keempat, Ada partisipasi aktif dan otonom para pihak

${ }^{17}$ Ibnu Artadi, Dekonstruksi Pemahaman Penyelesaian Sengketa Bisnis (Ekonomi dan Keuangan) Beraspek Pidana Melalui Prosedur Perdamaian -Menuju Proses Peradilan Pidana Rekonsiliatif-, Jurnal Hukum Responsif, Vol 1 (tahun tidak disebutkan) Hlm. 27

18 Sahuri Lasmadi, Mediasi Penal dalam Sistem Peradilan Pidana Indonesia, Makalah oleh Dosen Fakultas Hukum dan Program Pascasarjana Universitas Jambi, Tahun tidak disebutkan. Hlm. 1

${ }^{19}$ Sudiarta, Negosiasi, Mediasai \& Arbitrasi, Pustaka Bangsa, Mataram, 2013, Hlm. Pengantar

${ }^{20}$ Barda Nawawi Arief, Mediasi Pidana (Penal Mediation) Dalam Penyelesaian Sengketa/Masalah Perbankan Beraspek Pidana Di Luar Pengadilan, bahan presentasi pada Dialog Interaktif Mediasi Perbankan, di Bank Indonesia Semarang, 13 Desember 2006
(Active and Autonomous Participation Parteiautonomie/Subjektivierung). ${ }^{21}$

Selain prinsip kerja tersebut, mediasi penal juga mengenal prinsip pemulihan korban dan menjadi prinsip utama dalam bekerjanya proses mediasi penal dalam hukum pidana positif. Cikal bakal pemulihan hak-hak korban menjadi prinsip fundamental yang ingin diperjuangkan terkait hak-hak korban yang mengalami dan menjadi korban tindak pidana. ${ }^{22}$

Istilah lain dari mediasi penal adalah restorative justce. Istilah Restorative Justice, atau Restorasi Justice dalam terjemahan bahasa Indonesia disebut dengan istilah Restorasi Keadilan. Restorative Justice merupakan alteratif atau cara lain peradilan kriminal dengan mengedepankan pendekatan integrasi pelaku disatu sisi dan korban/masyarakat di lain sisi sebagai satu kesatuan untuk mencari solusi serta kembali pada pola hubungan baik dalam masyarakat. ${ }^{23}$

Prinsip mediasi penal (penal mediation) atau peradilan restoratif (restorative justice) sesuai dengan jati diri dan ideologi bangsa Indonesia yang termaktub dalam Pancasila yang merupakan core philosophy bangsa yang dijadikan sebagai ground norm untuk semua nilai yang hidup dalam kehidupan bangsa Indonesia.

Proses mediasi penal yang terjadi dan menciptakan keadilan akan meningkatkan perlindungan dan penegakkan hak asasi manusia guna berkembangnya pribadi manusia Indonesia dan kemampuannya dibidang

${ }^{21}$ Ibid

22 Sandy Ari Wijaya, Prinsip Mediasi Penal Dalam Tindak Pidana KDRT, Jurnal IUS Prulalisme Hukum, 2014, Vol. 2 No. 6, Hlm. 518

23 Kuat Puji Prayitno, Restorative Justice untuk Peradilan di Indonesia (Prespektif Yuridis Filosofis dalam Penegakan Hukum In ConCreto), Jurnal Dinamika Hukum, Vol. 12, No. 3, (September 2012). Hlm. 410 
Zahratul Ain Taufik |Penyelesaian Kasus Pelanggaran Ham Berat Melalui Pola Rekonsiliasi Pasca Putusan.....

kehidupan, hal ini berlandaskan pada UU No. 39 Tahun 1999 tentang HAM. ${ }^{24}$

\section{d. Rekonsiliasi Sebagai Alternatif Pe- nyelesaian Kasus-Kasus Pelangga- ran HAM Berat}

Makna rekonsiliasi dalam konteks alternatif penyelesaian kejahatan masa lalu adalah kesediaan memaafkan atau melupakan sejarah pahit demi menciptakan tatanan politik yang lebih baik dimasa depan. Singkatnya rekonsiliasi lebih meningkatkan pencapaian tujuan akhir itu daripada penuntutan pidana. ${ }^{25}$ Rekonsiliasi memiliki implikasi membangun atau membangun kembali hubungan yang tidak lagi dihantui konflik dan kebencian masa lalu. ${ }^{26}$

Menurut Daan Bronkhorst rekonsiliasi harus didasarkan pada fakta: adanya pengakuan atas kejahatan-kejahatan yang telah dilakukan, perubahan sifat transisi masa lampau yang keras ke arah sifat masa kini yang agak lunak, tradisi-tradisi negara, pertimbangan-pertimbangan politik nasional, internasional dan lain sebgainya. ${ }^{27}$

Hayner ${ }^{28}$ menjelaskanbahwa, melakukan perdamaian atau rekonsiliasi tidak sematamata mengembalikan hubungan baik, namun juga "mendamaikan" fakta-fakta atau kisah-kisah yang bertentangan, "membuat fakta-fakta atau pernyataanpernyataan yang bertentangan menjadi konsisten, bersesuaian atau kompatibel satu sama lain". ${ }^{29}$ Menurut Hayner, seringkali terdapat anggapan bahwa mengetahui

\footnotetext{
${ }^{24}$ Ibid Hlm. 519

${ }^{25}$ Rekonsiliasi sebagai tujuan, Versi Ramah Cetak, di akses melalui www.elsam.or.id

${ }^{26}$ Priscilia B. Hayner, Kebenaran Tak Terbahasakan: Refleksi Pengalaman Komisi-Komisi Kebenaran, Kenyataan dan Harapan, Op.Cit. Hlm. 131

${ }^{27}$ Ibid

${ }^{28}$ Priscilia B. Hayner, Unspeakable Truths Transitional Justice and the Challenge of Truth Commissions, Op.Cit. Hlm. 198

${ }^{29}$ To reconcile means not only reestablishing friendly relations but reconciling contradictory facts or stories, "to make (discordant facts, statements, etc.) consistent, accordant, or compatible with each other."
}

kebenaran tentang masa lalu merupakan syaratmutlakuntukterjadinyarekonsiliasi. ${ }^{30}$

Pada prinsipnya, menurut Lambang Triharyno, rekonsiliasi harus menekankan pada jalan ekspos dan responsibilitas. Ekspos ini agak ringan dibanding pengadilan tapi memiliki kekuatan guna memperbaiki hubungan antara korban dan pelaku. ${ }^{31}$ Lebih lanjut, Lambang menjeaskan bahwa tanggung jawab merupakan elemen terpenting dari rekonsiliasi, setidaknya rekonsiliasi memiliki elemen, yaitu responsibility dan ability. ${ }^{32}$

Selain ekspos dan tanggung jawab dari para pelaku, menurut Alex Laturiu, elemen yang tidak kalah penting dalam sebuah rekonsiliasi adalah pengakuan pelaku dan pemaafan korban. Karena menurutnya, dengan rekonsiliasi bisa berdialog langsung antara korban dan pelaku dan lantas pelaku mengadakan pengakuan kemudian korban bersedia meminta maaf. ${ }^{33}$

Hal-hal yang mendorong munculnya keinginan untuk melakukan sebuah rekonsiliasi, Priscilia B. Hayner menyarankan lima elemen berikut: ${ }^{34}$

- Penghentian kekerasan atau ancaman kekerasan;

- Pengakuan dan pemberian pemulihan (ganti rugi);

- Pengikat masyarakat;

- Menyelesaikan ketidaksetaraan struktural dan kebutuhan materil;

\footnotetext{
${ }^{30}$ Priscilia B. Hayner, Kebenaran Tak Terbahasakan Refleksi Pengalaman Komisi-Komisi Kebenaran, Kenyataann dan Harapan, Op.Cit, Hlm. 126

31 Lambang Triharyno, Esensi Rekonsiliasi, dalam Ifdhal Kasim \& Eddie Riyadi Terre, Kebenaran Vs Keadilan Pertanggungjawaban Pelanggaran HAM di Masa Lalu, Elsam, Jakarta, 2003, Hlm.70

${ }^{32}$ Ibid

${ }^{33}$ Alex Laturiu, Ibid, Hlm. 73

${ }^{34}$ Priscilia B. Hayner, Kebenaran Tak Terbahasakan Refleksi Pengalaman Komisi-Komisi Kebenaran, Kenyataann dan Harapan, Op.Cit,
} 
- Waktu,karenarkonsiliasijarangterjadi dengan segera.

\section{e. Sekilas tentang rencana pembentu- kan Komisi Kebenaran dan Rekon- siliasi (KKR) dalam Undang-Un- dang 27 Tahun 2004 tentang KKR sebelum dibatalkan oleh Mahkamah Konstitusi}

Pada awalnya, isu tentang KKR lebih merupakan inisiatif para elite politik era transisi awal yang disampaikan secara sepotong-potong dan lebih dalam nuansa serta kegunaan politik yang kabur dan berubah-ubah. ${ }^{35}$ Pada tahun 1998, Gagasan pembentukan KKR disuarakan dan didorong oleh berbagai kalangan. Gagasan tersebut ditindak lanjuti dengan adanya kesepakatan antara Komnas HAM dengan pihak pemerintah untuk membentuk Tim Informal Rekonsiliasi Nasional. ${ }^{36}$ Pemerintah transisi Indonesia dituntut mampu menarik garis demarkasi (batas pemisah) dengan rezim masa lalu dengan melakukan upaya penegakan hukum dan HAM. $^{37}$

Pada tanggal 26 Mei 2003 pemerintah menyerahkan Draft tersebut kepada DPR, dan pada 6 Oktober 2004 RUU KKR tersebut disahkan menjadi Undang-Undang, tepatnya menjadi Undang-Undang Nomor 27 Tahun 2004 tentang Komisi Kebenaran dan Rekonsiliasi yang selanjutnya disebut UU KKR. ${ }^{38}$ Belum lama setelah terbentuk UU KKR pada oktober 2004. Pada tahun 2006 muncul upaya yudisial review terhadap undang-undang tersebut oleh para korban

35 Robertus Robet, Politik Hak Asasi Manusia dan Transisi di Indonesia Sebuah Tinjauan Kritis, Elsam, Jakarta, 2008, Hlm. 96

36 Elsam, Mendorong Pembentukan Kembali UU Komisi Kebenaran dan Rekonsiliasi, Laporan terkait Pandangan ELSAM Mengenai Pentingnya RUU Komisi Kebenaran dan Rekonsiliasi, tahun tidak disebutkan, Hlm. 2 193

${ }^{37}$ Mahrus Ali dan Syarif Nurhidayat, Op.Cit, Hlm.

${ }^{38}$ Mahrus Ali dan Syarif Nurhidayat, Op.Cit, Hlm. 195 dan sejumlah LSM yang menyatakan bahwa ada beberapa pasal yang tidak sesuai atau bertentangan dengan Undang-Undang Dasar.

Perlu diketahui sebelumnya, bahwa sebuah rekonsialiasi akan sulit dilaksanakan tanpa adanya sebuah komisi atau sebuah atau sekelompok orang yang membentuk dirinya atas dasar kemanusiaan untuk menyelesaikan perkara-perkara pelanggaran HAM. KKR, menurut Danil Sparringa merupakan pilihan yang masuk akal dalam menggerakan kualitas perubahan tatkala diletakan pada kerangka menyelesaikan masa lampau dan menyelamatkan masa depan. ${ }^{39}$

Tujuan makro dari KKR menurut Abdul Hakim Garuda Nusantara adalah 1) mendata semua peristiwa yang berhubungan dengan tindak pelanggaran HAM; 2) melakukan verifikasi terhadap semua kejadian pelaggaran HAM masa lampau yang merupakan akibat dari sistem otoritarian; 3) hasilnya dipublikasikan dengan memuat laporan kejadian dan sejumlah rekomendasi yang bersifat kebijakan. ${ }^{40}$

Upaya maksimal yang dapat dilakukan oleh lembaga ini adalah mengidentifikasi pelaku dan mengungkap nama mereka kepada publik (naming name). Namun ini pun biasanya hanya terbatas pada pelaku yang paling bertanggung-jawab atas kasus tersebut (the most responsible perpetrators). Bahkan kepada pelaku - khususnya yang kooperatif dengan Komisi ini- akan diberikan pengampunan (amnesty). ${ }^{41}$

\section{f. Pola penyelesaian pelanggaran HAM berat pasca putusan MK NO. 006/PUU-IV tahun 2006 tentang pengujian terhadap Undang-Un-}

39 Danil Sparringa, Menghadapi Masa Lampau, dalam Ifdhal Kasim dan Eddie Riyadi Terre, Op.Cit Hlm.13

${ }^{40}$ Abdul Hakim Garuda Nusantara, dalam Ibid, Hlm. 17-18

${ }^{41}$ Indriaswaty D. Saptaningrum, dkk, Op.Cit. Hlm. 16 
Zahratul Ain Taufik |Penyelesaian Kasus Pelanggaran Ham Berat Melalui Pola Rekonsiliasi Pasca Putusan.....

dang No. 27 Tahun 2004 tentang Komisi Kebenaran Dan Rekonsiliasi

Penyelesaian pelanggaran berat HAM masa lalu di Indonesia, menurut Agus Raharjo, terdapat tiga pendekatan utama, diantaranya adalah: ${ }^{42}$

1) Dengan memaafkan dan melupakan apa yangtelahterjadi,kemudian"melanjutkan hidup" begitu saja;

2) Dengan menuntut semua pelaku melalui jalur hukum dengan menciptakan suatu pengadilan HAM;

3) Menerima apa yang terjadi di masa lalu, sampai pada suatu tingkat dan kondisi tertentu, dengan fokus tujuan pada menguak kebenaran dan menyediakan kompensasi dan rehabilitasi untuk para korban dengan mendirikan suatu "Komisi Kebenaran", dan hanya menuntut pelaku utama untuk diajukan ke pengadilan.

Pola penyelesaian pelanggaran HAM berat, terutama pelanggaran HAM berat di masa lalu dapat diselesaikan melalui jalan rekonsiliasi, sejalan dengan salah satu pendekatan utama dalam penyelesaian pelanggaran HAM berat masa lalu berdasarkan pendapat Agus Raharjo. Salah satu unsur penting dalam sebuah rekonsiliasi adalah pengungkapan kebenaran. Pengungkapan kebenaran adalah sebuah proses yang dilakukan seusai jatuhnya sebuah rezim yang otoriter atau setelah konflik berlalu. Proses ini mencakup langkah-langkah investigatif untuk membantu masyarakat memahami praktek penyalahgunaan kekuasaan yang mengakibatkan banyaknya pelanggaran HAM berat. $^{43}$

${ }^{42}$ Agus Raharjo, Implikasi Pembatalan Undang-Undang Komisi Kebenaran Dan Rekonsiliasi Terhadap Prospek Penanganan Pelanggaran Berat Hak Asasi Manusia, Jurnal Mimbar Hukum. Vol. 19, No 1 (Februari 2007) Hlm. 5

${ }^{43}$ Kontras, Memahami Komisi Kebenaran dan Rekonsiliasi, selebaran (leaflet), diolah dari berbagai sumber untuk disosialisasikan kepada korban pelanggaran
Pengungkapan kebenaran dimaksud, dapat terungkap dengan dilakukannya berbagai proses penyelidikan terkait pelanggaran HAM yang pernah terjadi. Penyelidikan yang dilakukan tersebut tentu saja tidak dilakukan oleh para korban atau para pelaku, namun penyelidikan tersebut dilakukan oleh sebuah komisi kebenaran, seperti yang disebutkan oleh Hayner.

Selain pola rekonsiliasi oleh sebuah komisi kebenaran, rekonsiliasi juga dapat dilakukan dengan pola rekonsiliasi yang dimulai dari komunitas terkecil di masyarakat.Proses rekonsiliasiyang diusung tersebut dilaksanakan dan didukung oleh masyarakat. Selain itu, peran kultural dan seremoni adat menjadi hal penting sebagai unsur pengikat rekonsiliasi. ${ }^{44}$

Qanun Aceh tentang KKRA juga menekankan bahwa sebuah proses rekonsiliasi menyeluruh dapat dilakukan jika terjadi permintaan maaf secara resmi, pengakuan tentang kejahatan di masa lalu, dan sebuah janji bahwa pelanggaran di masa lalu tidak akan terulang lagi di masa yang akan datang. ${ }^{45}$

\section{Pengaturan Rekonsiliasi yang Dapat Diterapkan dalam Penyelesaian Kasus Pelanggaran HAM Berat di Indonesia Pasca Putusan MK No. 006/PUU-IV Ta- hun 2006 tentang Pengujian UU No. 27 Tahun 2004 tentang KKR}

\section{A. Penyelesaian Pelanggaran HAM Berat di Daerah Papua}

1) Sekilas tentang Kasus Pelanggaran HAM Berat di Daerah Papua

Perlakuan yang dianggap sebagai pelanggaran HAM berat dimulai sejak OtoritasEksekutifSementaraPBB(UNTEA)

HAM berat di Aceh perihal Komisi Kebenaran dan Rekonsiliasi, Tahun tidak disebutkan

${ }^{44}$ Tim Koalisi Pengungkap Kebenaran (KPK) Aceh, Tawaran Model Penyelesaian Pelanggaran Berat HAM di Aceh, 2007, Hlm. 30

${ }^{45}$ Ibid 
menyerahkan otoritas pemerintahan Papua ke Indonesia pada tanggal 1 Mei 1963. Lima tahun sejak penyerahan otoritas pemerintahan ke Indonesia, Sekjen PBB menunjuk perwakilan khusus untuk "memberikan saran, membantu dan terlibat dalam penyelenggaraan penentuan pendapat, yang menjadi tanggung jawab Indonesia, untuk tetap bersama Indonesia atau melepaskan diri." Namun, sebelum digelarnya Penentuan Pendapat Rakyat atau Pepera (Act of Free Choice) pada tahun 1969, militer Indonesia mulai melakukan tekanan terhadap berbagai aksi politik di Papua. ${ }^{46}$

Setelah pelaksanaan Pepera, resistensi terhadap integrasi muncul dalam banyak bentuk, seperti separatisme bersenjata, deklarasi politik, pengibaran bendera, demonstrasi damai, pengasingan diri ke luar negeri, perusakan harta benda, penyanderaan, dan sebagainya. Reaksi militer yang dilakukan itu pun tidak hanya dilakukan terhadap separatis bersenjata tetapi juga dilakukan terhadap warga sipil di daerah konflik, demonstran damai, dan pemimpin politik dan etnis. ${ }^{47}$

2) Upaya Pemerintah dalam Menyelesaikan Pelanggaran HAM berat di daerah Aceh

Usaha pemerintah dalam menyelesaikan kasus pelanggaran HAM berat masa lalu yang terakomodir dalam UU No. 21 Tahun 2001 tentang Otonomi Khusus bagi Provinsi Papua. Dalam Pasal 45 ayat (1) dan ayat (2), Pemerintah mengakomodir penyelesaian pelanggaran HAM berat dilakukan juga oleh pemerintah daerah. Seperti dalam Bab XII yang membahas mengenai HAM.

Namun Pemerintah belum berhasil membentuk KKR Papua dengan UU No. 21 Tahun 2001 tentang Otonomi Khusus bagi Provinsi Papua, selain itu, pemerintah juga belum memenuhi mandat UU

${ }^{46}$ International Center for Transitional Justice (ICTJ) dan ELSHAM (Lembaga Studi dan Advokasi Hak Asasi Manusia), Op.Cit. Hlm. 7

${ }^{47}$ Ibid
Otonomi Khusus Papua untuk membentuk Pengadilan HAM di Papua.

UU No. 21 Tahun 2001 tentang Otonomi Khusus Papua kemudian diperbaharui dengan UU No. 35 Tahun 2008 tentang Penetapan Perpu Nomor 1 Tahun 2008 tetang Perubahan atas UU No. 21 Tahun 2001 tentang Otonomi Khusus Papua yang di dalamnya membagai Provinsi Papua menjadi dua bagian yakni dengan menambahkan Provinsi Papua Barat. ${ }^{48}$ Yang kemudian hal tersebut menjadi kendala dalam menjalankan amanat UU No. 21 Tahun 2001 tentang Otonomi Khusus Papua dalam hal pembentukan KKR Papua dan pengadilan HAM di Papua.

\section{B. Putusan Mahkamah Konstitusi No- mor 006/PUU-IV Tahun 2006 ten- tang Pengujian Undang-Undang No- mor 27 Tahun 2004 tentang Komisi Kebenaran dan Rekonsiliasi ${ }^{49}$}

Salah satu fungsi Mahkamah Konstitusi adalah untuk mengawal konstitusi agar dilaksanakan dan dihormati baik oleh penyelenggara negara maupun warga negara. Sejak di inkorporasikannya hakhak asasi manusia dalam UUD 1945, bahwa fungsi pelindung konstitusi dalam arti melindungi hak-hak asasi manusia adalah benar adanya. ${ }^{50}$

Secara umum, MKRI mempunyai empat kewenangan dan satu kewajiban, sebagaimana yang tertuang dalam Pasal 24C ayat (1) dan (2) UUD 1945. Diantara kewenangannya tersebut, Mahkamah Konstitusi berwenang menguji undang-

\footnotetext{
${ }^{48}$ Komnas HAM, Upaya Negara Menjamin Hak-Hak Kelompok Minoritas di Indoneisia, Laporan, 2016, Hlm.

${ }^{49}$ Putusan Mahkamah Konstitusi Nomor 006/PUUIV Tahun 2006 tentang Pengujian Undang-Undang Nomor 27 Tahun 2004 tentang Komisi Kebenaran dan Rekonsiliasi, yang diputuskan pada RPH Senin, 4 Desember 2006, dan diucapkan pada Sidang Pleno Mahkamah Konstitusi pada Kamis, 7 Desember 2006

50 AD. Basniwati, Kedudukan dan Wewenang Mahkamah Konstitusi dalam Sistem Ketatanegaraan republik Indonesia, Jurnal IUS, Vol. 2, No. 5, Agustus 2014, Hlm. 258-259
} 40 
Zahratul Ain Taufik |Penyelesaian Kasus Pelanggaran Ham Berat Melalui Pola Rekonsiliasi Pasca Putusan.....

undang terhadap UUD 1945. Dalam hal menjalankan kewenangannya, pada Selasa tanggal 28 Maret 2006 Mahkamah Konstitusi Republik Indonesia (MKRI) menerima sebuah permohonan pengujian UU No. 27 Tahun 2004 tentang KKR dan permohonan tersebut teregistrasi pada Rabu tanggal 29 Maret 2006 dengan Nomor 006/PUU-IV/2006.

Pokok-pokok yang dijadikan sebagai objek uji materil dalam perkara tersebut adalah Pasal 27, Pasal 44, dan Pasal 1 Angka 9 UU No. 27 Tahun 2004 tentang Komisi Kebenaran dan Rekonsiliasi. Yang mana Dianggap Bertentangan masing masingnya dengan Pasal 27 Ayat (1), 28D Ayat (1), 28I Ayat (2); Pasal 28D Ayat (1) dan Pasal 28I Ayat (4); Pasal 28D Ayat (1) dan 28I Ayat (5) UUD 1945.

Berdasarkan permohonan pengujian undang-undang tersebut MK bukan hanya mempertimbangkan pasal-pasal yang menjadi pokok uji materil, namun juga mempertimbangkan lain, yaitu mengeluarkan putusan yang melebihi ultra petita ${ }^{51}$. Pertimbangan tersebut yang akhirnya mendapat keputusan final, yakni Dibatalkannya UU No. 27 Tahun 2004 tentang Komisi Kebenaran dan Rekonsiliasi.

\footnotetext{
${ }^{51}$ Ultra petita adalah penjatuhan putusan oleh hakim atas perkara yang tidak dituntut atau mememutus melebihi dari pada yang diminta. Dalam Ibnu Sina Chandranegara, Ultra Petita dalam Pengujian Undang-Undang dan Jalan Mencapai Keadilan Konstitusional, Jurnal Konstitusi, Volume 9, Nomor 1, Maret 2012, Hlm. 28., Lihat Ketentuan ultra petita diatur dalam Pasal 178 ayat (2) dan (3). Het Herziene Indonesisch Reglement (HIR) serta padanannya dalam Pasal 189 ayat (2) dan (3) RBg (Rechtsreglement Buitengewesten),. Lihat isi Pasal 178 ayat (2) "hakim itu wajib mengadili segala bagian tututan" dan ayat (3)"hakim akan dilarang akan menjatuhkan keputusan atas perkara yang tiada dituntut, atau akan meluluskan lebih dari pada yang dituntut" dalam R. Tresna, Komentar HIR, Pradnya Paramita, Jakarta, 2005, Hlm. 158., Lihat juga penjelasan singkat Pasal 189 ayat (2) dan (3) RBg mengenai "Pengadilan dapat mengabulkan lebih dari yang digugat, asal masih sesuai dengan kejadian materil", dalam Hari Sasangka dan Ahmad Rifai, "Perbandingan HIR dengan RBG Disertai dengan Yurisprudensi MARI dan Kompilasi Peraturan Hukum Acara Perdata”, Mandar Maju, Kediri, 2005.
}

Selain adanya ultra petita pada putusan MK, dalamputsanitujugaMKmenganjurkan beberapa hal yang dapat ditempuh dalam penuntasan kasus pelanggaran HAM berat. Hal tersebut adalah sebagai berikut: ${ }^{22}$

1) Mewujudkan rekonsiliasi dalam bentuk kebijakan hukum (undangundang) yang serasi dengan UUD 1945 dan instrumen HAM yang berlaku secara universal;

2) Melakukan rekonsiliasi melalui kebijakan politik dalam rangka rehabilitasi dan amnesti secara umum.

Anjuran yang disampaikan MK dalam putusannya tersebut menurut R. Herlambang P. Wiratraman, ${ }^{53}$ bukan persoalan yang mudah, karena perspektif yang digunakan oleh MK lebih berpusat pada state based perspective ${ }^{54}$ daripada memperhatikan victim based $^{55}$.

Kebijakan hukum sebagaimana dimaksudkan MK ditafsirkan pula oleh R. Herlambang P. Wiratraman, berupa: ${ }^{56}$

(1) membentuk Pengganti UndangUndang Nomor 27Tahun2004 tentang KKR;

(2) memperbaiki kerangka hukum UU No. 26 tahun 2000 tentang Pengadilan HAM yang juga ditunjuk untuk menyelesaikan kasus pelanggaran HAM berat, agar lebih memenuhi standarhukumHAMinternasionaldan lebih efektif dalam proses penegakan hukumnya yang bisa meminta pertanggungjawaban aktor yang paling bertanggung jawab;

\footnotetext{
52 Lihat Putusan MK Nomor 006/PUU-IV/2006, Op.Cit.

${ }^{53}$ R. Herlambang P. Wiratraman, Akses Keadilan Bagi Korbann Pelanggaran HAM Pasca Putusan MK No. 006/PUU-IV/2006, Jurnal Recht Vinding, Vol. 2, No. 2, (Agustus 2013), Hlm. 188

${ }^{54}$ Perspektif berbasis kepentingan negara atau tindakan yang mendasarkan pada kebijakan politik penguasa

${ }_{55}$ Perspektif berbasis kepentingan korban

${ }^{56}$ R. Herlambang P. Wiratraman, Op.Cit. Hlm. 190
} 
(3) memperbarui perundang-undangan yang dinilai merugikan bagi akses keadilan bagi korban dan keluarga korban pelanggaran HAM berat, baik dengan mencabut, mengganti, atau membentuk aturan baru yang sifatnya lebih melindungi dan memenuhi hakhak korban dan keluarganya.

\section{Penyelesaian Kasus Pelanggaran HAM Berat di Indonesia Pasca Pu- tusan MK NO. 006/PUU-IV Tahun 2006 tentang Pengujian UU No. 27 Tahun 2004 Tentang KKR}

1) Penyelesaian Pelanggaran HAM berat di daerah Aceh

a. Sekilas mengenai pelanggaran HAM berat di daerah Aceh $^{57}$

PelanggaranHAMterjadidiAcehsejak periode tahun 1953 s.d. 1963, ada juga kejadian konflik politik pada 1965 s.d. 1970. Sebelum dinyatakan sebagai Daerah OperasiMiliter,pada1976s.d.1989disebut Pra DOM. Sampai pada Pada 1989-1998 pemerintah Indonesia menetapkan status Provinsi Aceh sebagai Daerah Operasi Militer (DOM). Hingga Pasca DOM pada 1998 s.d. 2005.

Dalam rentang waktu 30 tahun DOM itu, ribuan orang di Aceh telah mengalami penyiksaan, pembunuhan, penghilangansecarapaksa,danperkosaan. Pernah ada Tim Independen Pengusutan Tindak Kekerasan di Aceh yang dibentuk oleh Presiden Habibie di tahun 1999. Dari laporan Tim Independen tersebut mencatat ada dua proses kekerasan yang terjadi

Pertama adalah kekerasan berlanjut. Artinya seseorang yang ditangkap aparat keamanan, kemudian mengalami

${ }^{57}$ Tim Koalisi Pengungkap Kebenaran (KPK) Aceh, Tawaran Model Penyelesaian Pelanggaran Berat HAM di Aceh, 2007, Hlm. 17, lihat juga Tim Penyusun Laporan Komnas Ham, Laporan Tahunan 2014, Komisi Nasional Hak Asasi Manusia Republik Indonesia, Jakarta, 2014, Hlm. 101 serangkaian kekerasan dalam pelbagai bentuk, kemudian ia dibunuh. Kedua kekerasan itu terjadi sangat tergantung pada kehendak aparat yang menangkap korban. Artinya kuantitas kekerasan yang dialami oleh seorang korban sangat sulit dikalkulasi

b. Upaya Pemerintah dalam Menyelesaikan Pelanggaran HAM berat di daerah Aceh

Tahun 2005, Pemerintah dan GAM duduk semeja di Helsinki untuk berundingdan menghasilkan Perjanjian damai Helsinski ${ }^{58}$ pada 15 Agustus 2005 menjadi titik awal perdamaian Aceh. Nota kesepahaman tersebut memiliki enam poin perjanjian damai yang setidaknya disepakati, yaitu menyangkut: 1) Penyelenggaraan pemerintahan di Aceh; 2) Hak Asasi Manusia; 3) Amnesti dan reintegrasi ke dalam masyarakat; 4) Pengaturan keamanan; 5) Pembentukan misi monitoring di Aceh; dan 6) Penyelesaian perselisihan. ${ }^{59}$

Terkaithak asasi manusia, dalam nota kesepahaman tersebut menegaskan tiga hal penting, yakni: ${ }^{60}$

(1) Pemerintah RI akan mematuhi Kovenan Internasional Perserikatan Bangsa-bangsa mengenai Hak-hak Sipil dan Politik dan mengenai Hakhak Ekonomi, Sosial dan Budaya;

(2) Sebuah Pengadilan Hak Asasi Manusia akan dibentuk untuk Aceh; dan

(3) Komisi Kebenaran dan Rekonsiliasi (KKR) akan dibentuk di Aceh oleh Komisi Kebenaran dan Rekonsiliasi Indonesia dengan tugas merumuskan dan menentukan upaya rekonsiliasi.

\footnotetext{
${ }^{58}$ Nama perjanjian damai tersebut diambil dari nama kota di Finlandia yaitu Kota Helsinki

${ }_{59}$ Nota Kesepahaman antara Pemerintah Republik Indonesia dan Gerakan Aceh Merdeka, ditandatangani di Helsinki, Finlandia pada Senin 15 Agustus 2005

${ }^{60}$ Ibid, Poin 2, Hlm. 5
} 
Zahratul Ain Taufik |Penyelesaian Kasus Pelanggaran Ham Berat Melalui Pola Rekonsiliasi Pasca Putusan.....

Padatahun2006,UUNo.11tahun2006 tentang Pemerintahan Aceh terbentuk dengan berdasar pada otonomi khusus terhadapdaerahAceh.Undang-undangini dibentuk sebagai tindak lanjut dari nota kesepahaman helsinski. Undang-undang ini juga memandatkan pembentukan KKR Aceh dan pengadilan HAM di Aceh. Pembentukan KKR Aceh dimaksudkan untuk menyelesaikan pelanggaran HAM masa lalu di Aceh yang merupakan bagian dari KKR Indonesia. ${ }^{61}$

Dalamkaitannyadenganpenyelesaian pelanggaran HAM yang terjadi di Indonesia, Khususnya di daerah Aceh, pemerintah Aceh bersama DPR Aceh membentuk Qanun Aceh Nomor 17 Tahun 2013 tentang Komisi Kebenaran dan Rekonsiliasi Aceh. Qanun Aceh tentangKKRA berisitentangkeseluruhan mengenai KKR.

Qanun Aceh tentang KKRA inibelum bisa berjalan sebagaimana mestinya. Karena KKRN (Komisi Kebenaran dan Rekonsiliasi Nasional) belum bisa terbentuk sampai sekarang pasca putusan MK tentang Pembatalan Undang-Undang Nomor 27 tahun 2004 tentang KKR pada Kamis 7 Desember 2006.

2) Penyelesaian Pelanggaran HAM berat di daerah Kotamadya Palu

a. SekilastentangpelanggaranHAMyang
terjadi di Kota Palu

Peristiwa pelanggaran HAM berat yang terjadi di daerah Palu, merupakan dampak yang meluas dari peristiwa yang sudah tidak asing lagi didengar, yakni peristiwa 1965-1966. Peristiwa 19651966 merupakanserangkaiperistiwayang terjadi secara berurutan baik sebelum tahun 1965 dan peristiwa penting pada tahun $1965 \mathrm{itu}$ sendiri, terutama peristiwa

${ }^{61}$ Lihat pasal 229 UU No. 11 Tahun 2006 tentang Pemerintahan Aceh. pembunuhan tujuh orang Jendral Angkatan Darat. ${ }^{62}$

Ketika PKI (Partai Komuis Indonesi) dituduh sebagai dalang dari pemberontakan G30S, serta merta para aktivis partai menjadi tujuan penangkapan, penahanan, penghilangan, pemerkosaan hingga pembunuhan. ${ }^{63}$ Dampak dari peristiwa tersebut, juga sampai di Kota Palu.

Situasi demonstrasi dan protes tersebut berlangsung dari bulan Oktober 1965 sampai Februari 1966. Situasi demonstrasi dan protes tersebut berlangsung dari bulan Oktober 1965 sampai Februari 1966. Karena situasi tersebut, Secara umum, muncul empat gelombang penangkapan dan penahanan yang terjadi di Kota Palu dan sekitarnya. ${ }^{64}$ Dalam catatan SKP-HAM ${ }^{65}$ Sulteng, sementara ini hanya ada satu kasus kematian terkait Peristiwa 1965/1966 di Kota Palu, yaitu kasus kematian akibat penyiksaan di tahanan yang terjadi pada Letnan Satu Karsono, anggota kesatuan Brawijaya yang dituduh sebagai simpatisan PKI. ${ }^{66}$

Mengacu pada laporan hasil penyelidikan projustisia Komnas HAM, Peristiwa1965/1966telahmengakibatkan terjadinya berbagai bentuk pelanggaran HAM yang berat. Berbagai bentuk pelanggaran HAM terkait Peristiwa 1965/1966 itu pun terjadi di Kota Palu.

62 Komnas HAM RI, Ringkasan Eksekutif Hasil Penyidikan Tim Ad Hoc Penyelidikan Pelanggaran HAM yang Berat Peristiwa 1965-1966, dalam Baskara T. Wardaya SJ., Luka Bngsa Luka Kita Pelanggaran HAM Masa Lalu dan Tawaran Rekonsiliasi, Galang Pustaka, Yogyakarta, 2014, Hlm. 54

${ }_{63}$ Nurlela A.K. Lamasitudju, Rekonsiliasi dan Pernyataan Maaf Pak Wali Kota, dalam Ibid., Hlm. 372

${ }^{64}$ Moh. Syafari Firdaus, Dkk, Ringkasan Eksekutif Penelitian dan Verifikasi Korban Pelanggaran Hak Asasi Manusia Peristiwa 1965/1966 di Kota Palu, Badan Perencanaan Pembangunan Daerah (Bappeda) Kota Palu; Solidaritas Korban Pelanggaran Hak Asasi Manusia (SKP-HAM) Sulteng, Palu, 2015, Hlm.12

${ }^{65}$ Solidaritas Korban Pelanggaran Hak asasi Manusia

${ }^{66}$ Moh. Syafari Firdaus, Dkk, Op.Cit, Hlm. 13 
Jenis dan bentuk pelanggaran HAM ini jika mengacu pada klasifikasi Huridocs (The Human Rights Information and Documentation Systems 'Sistem Informasi dan Dokumentasi Hak Asasi Manusia'), maka dapat dikategorikan berdasarkan bentuk dan jenisnya, ada 16 bentuk dan jenispelanggaranHAMyangterjaditerkait dengan Peristiwa 1965/1966 di Kota Palu. 16 bentuk dan jenis Pelanggaran HAM tersebut adalah: ${ }^{67}$

1) Kerja paksa;

2) wajib lapor;

3) penyiksaan;

4) penangkapan sewenangwenang;

5) penahanan sewenang-wenang;

6) pengambilan dan pemutusan sumber penghidupan;

7) perilaku kejam \& tidak manusiawi;

8) pemerasan;

9) pencurian/penjarahan/perampokan barang milik;

10) pengadilan yang tidak adil;

11) pembiaran yang mengakibatkan kematian;

12) penghilangan paksa;

13) kekerasan seksual;

14) pembakaran dan pengrusakan rumah danbarang milik;

15) usaha eksekusi; dan

16) perkosaan.

b. Upaya Pemerintah Kotamadya Palu dalam Melakukan Penyelesaian kasus Pelanggaran HAM Di Kota Palu

Upaya pemerintah palu dalam menyelesaikan kasus pelanggaran HAM berat di daerahnya adalah berawal dari permohonan maaf Wali Kota Palu periode 2005 -2015, Rusdi Mastura.

\footnotetext{
${ }^{67}$ Ibid, Hlm. 17
}

Beliau menyampaikan permohonan maafnya kepada korban tragedi '65, baik sebagai pribadi maupun sebagai Kepala Pemerintah Daerah Kota Palu.

Setelah meminta maaf, ia menyanggupi tuntutan SKP-HAM untuk memberikan reparasi bagi korban dan keluarganya. Lebih lanjut pak Wali Kota juga berjanji untuk merealisasikan perbaikan yang dipandang sangat mendesak bagi korban dan keluarganya, berupa jaminan kesehatan gratis, beasiswa, jaminan hari tua dan bantuan usaha. Biaya perbaikan tersebut telah dianggarkan dalam Anggaran Pendapatan Belanja Daerah Kota Palu tahun 2013. ${ }^{68}$

Permintaan maaf Walikota Palu tersebut ditindaklanjuti dengan diterbitkannya Peraturan Walikota Palu Nomor 25 Tahun 2013 tentang Rencana Aksi Hak Asasi Manusia Daerah yang memuat tentang pengakuan terhadap korban dugaan pelanggaran HAM dan mengamantkan pemenuhan HAM bagi para korban pelanggaran HAM. Proses Penyelesaian Pelanggaran HAM Masa Lalu di Kotamadya Palu sejauh ini sudah berjalan dengan lancar. Anggaran proses tersebut menggunakan Anggaran Pendapatan dan Belanja Daerah (APBD).

Implementasi dari Perwali mencakup berbagai hal, tidak hanya mendorong pengungkapan kebenaran dan bantuan untuk pemulihan hak-hak korban, tetapi juga upaya menciptakan suatu proses transformasi sosial di Kota Palu untuk memastikan adanya perubahan paradigma, penghapusan stigmatisasi, dan mendorong rekonsiliasi antara masyarakat dengan korban Peristiwa $1965-1966 .{ }^{69}$

\footnotetext{
${ }^{68}$ Lebih jelasnya lihat pada, Ibid, Hlm. 383

${ }^{69}$ Elsam, Praktik Terbaik dari Palu untuk Penyelesaian Pelanggaran HAM Masa Lalu, Dalam http://elsam. or.id/2016/03/praktik-terbaik-dari-palu-untuk-penyelesaian-pelanggaran-ham-masa-lalu, diakses pada Rabu 29 Maret 2017 pukul 12:11 wita
} 
Zahratul Ain Taufik | Penyelesaian Kasus Pelanggaran Ham Berat Melalui Pola Rekonsiliasi Pasca Putusan.....

\section{SIMPULAN}

Pola rekonsiliasi yang ditemukan dalam tulisan ini ada dua model, yakni:Kasuskasus pelanggaran HAM berat sebelum tahun 2000 diselesaikan dengan pola rekonsiliasi. Untuk mencapai sebuah rekonsiliasi diperlukan penyelidikan yang dilakukan oleh lembaga independen yang dibentuk pemerintah. Lembaga independen disebut Komisi Kebenaran dan Rekonsiliasi (KKR). Pola yang kedua yang ditemukan dalam penelitian ini dan telah berhasil dilaksanakan di salah satu daerah di Indonesia adalah rekonsiliasi yang dilakukan secara kekeluargaan yang terjadi di daerah Kota Palu. Rekonsiliasi di Kota Palu dimulai dari komunitas terkecil di masyarakat. Proses rekonsiliasi yang diusung tersebut dilaksanakan dan didukung oleh masyarakat. Selain itu, peran kultural dan seremoni adat menjadi hal penting sebagai unsur pengikat rekonsiliasi.

Pengaturan rekonsiliasi yang telah ada di beberapa daerah di Indonesia. Dalam UU No 21 Tahun 2001 tentang Otonomi Khusus Papua, mengamanatkan bahwa tugas KKR Papua adalah untuk melakukan klarifikasi sejarah dan merumuskan sertra menetapkan langkah-langkah rekonsiliasi. Dalam UU No 11 tahun 2006 tentang Pemerintahan Aceh, memandatkan pembentukan KKR Aceh dan pengadilan HAM di Aceh. Perwali Palu No 25 Tahun 2013 tentang RAN HAM Daerah, memuat tentang pengakuan terhadap korban dugaan pelanggaran HAM dan mengamantkan pemenuhan HAM bagi para korban pelanggaran HAM.

\section{DAFTAR PUSTAKA}

\section{Buku-buku}

Antonius Sumarwan, Menyebrangi Sungai Air Mata: Kisah Tragis TAPOL'65 dan Upaya Rekonsiliasi, Kanisius, Yogyakarta: 2007

Baskara T. Wardaya SJ., Luka Bngsa Luka Kita Pelanggaran HAM Masa Lalu dan Tawaran Rekonsiliasi, Galang Pustaka, Yogyakarta, 2014

IfdhalKasim \&Eddie Riyadi Terre, Kebenaran Vs Keadilan Pertanggungjawaban Pelanggaran HAM di Masa Lalu, Elsam, Jakarta, 2003

Eddy O.S. Hiariej, Asas Legalitas dan Penemuan Hukum dalam Hukum Pidana, Erlangga, Jakarta: 2009

Hari Sasangka dan Ahmad Rifai, "Perbandingan HIR dengan RBG Disertai dengan Yurisprudensi MARI dan Kompilasi Peraturan Hukum Acara Perdata", Mandar Maju, Kediri, 2005

Hesti Armiwulan Sochmawardiah, Diskriminasi Rasial dalam Hukum HAM, Genta Publishing, Yogyakarta, 2013

Ibnu Sina Chandranegara, Ultra Petita dalam Pengujian Undang-Undang dan Jalan Mencapai Keadilan Konstitusional, Jurnal Konstitusi, Volume 9, Nomor 1, Maret 2012

Indriaswaty D. Saptaningrum, dkk, Menjadikan HAM sebagai Hak Konstitusional: Pandangan Kritis atas Putusan Mahkamah Konstitusi terhadap Judicial Review UU KKR dan Implikasinya bagi Penyelesaian Pelanggaran HAM di Masa Lalu, ELSAM, Jakarta, 2007

International Center for Transitional Justice (ICTJ) dan ELSHAM (Lembaga Studi dan Advokasi HAM), Masa Lalu yang Tak Berlalu: Pelanggaran Hak Asasi Manusia di Tanah Papua Sebelum dan Sesudah Reformasi, ICTJ, 2012

Mahrus Ali dan Syarif Nurhidayat, Penyelesaian Pelaggaran HAM Berat In Court Syistem \& Out Court System, Gramata Publishing, Depok, 2011 
Mien Rukmini, Perlindungan HAM melaui Asas Praduga Tidak bersalah dan Asas Persamaan Kedudukan di Depan Hukum pada Sistem Peradilan Pidana Indoesia, Ed. 1, Cet.1, Alumni, Bandung, 2003

Moh. Syafari Firdaus, Dkk, Ringkasan Eksekutif Penelitian dan Verifikasi Korban Pelanggaran Hak Asasi Manusia Peristiwa 1965/1966 di Kota Palu, Badan Perencanaan Pembangunan Daerah (Bappeda) Kota Palu; Solidaritas Korban Pelanggaran Hak Asasi Manusia (SKP-HAM) Sulteng, Palu, 2015

Muhammad Jailani \& Lalu Adnan Ibrahim, Mengenal Pengadilan Kriminal Internasional dan Pengadilan HAM di Indonesia, Pustaka Bangsa, Mataram:2016

Priscilia B. Hayner, Kebenaran Tak Terbahasakan: Refleksi Pengalaman Komisi-Komisi Kebenaran, Kenyataan dan Harapan, terjemahan Tim Penerjemah Elsam, Elsam, Jakarta 2005

-------, Unspeakable Truths Transitional Justice and the Challenge of Truth Commissions , Routledge, New York, 2011

Robertus Robet, Politik Hak Asasi Manusia dan Transisi di Indonesia Sebuah Tinjauan Kritis, Elsam, Jakarta, 2008

R. Tresna, Komentar HIR, Pradnya Paramita, Jakarta, 2005

Sudiarta, Negosiasi, Mediasai \& Arbitrasi, Pustaka Bangsa, Mataram, 2013

Suparman Marzuki, Pengadilan HAM di Indonesia Melanggengkan Impunity, Erlangga, Jakarta:2012

Suratman, \& Philips Dillah, Metode Penelitian Hukum, Alfabeta: Bandung, 2013
Tim Koalisi Pengungkap Kebenaran (KPK) Aceh, Tawaran Model Penyelesaian Pelanggaran Berat HAM di Aceh, 2007

Tim Penyusun Kamus Pusat Bahasa, Kamus Besar Bahasa Indonesia, Departemen Pendidikan Nasional, Ed. 3, Cet. 3, Balai Pustaka, Jakarta, 2002

Zainudin Ali, metode penelitian hukum, Cet. 1, Sinar Grafika, Jakarta, 2009,

\section{Peraturan Perundang-Undangan dan Putusan Pengadilan}

Indonesia, Undang-Undang Dasar Negara Republik Indonesia, Tahun 1945

Indonesia, Undang-Undang tentang HAM, UU No. 39 Tahun 1999, LN. No.165 Tahun 1999

Indonesia, Undang-Undang tentang Pengadilan HAM, UU No. 26 Tahun 2000, LN. No. 208 Tahun 2000

Indonesia, Undang-Undang tentang Otonomi Khusus bagi Provinsi Papua UU No 21 Tahun 2001, LN. No.135 Tahun 2001

Indonesia, Undang-Undang tentang Pemerintahan Aceh, UU No. 11 tahun 2006, LN. 62 Tahun 2006

Indonesia, Peratyran Wali Kota Palu tentang RAN HAM Daerah, Perwali No. 25 Tahun 2013, LD. Tahun 2014

Putusan Mahkamah Konstitusi Nomor 006/PUU-IV Tahun 2006 tentang Pengujian Undang-Undang Nomor 27 Tahun 2004 tentang Komisi Kebenaran dan Rekonsiliasi, yang diputuskan pada RPH Senin, 4 Desember 2006, dan diucapkan pada Sidang Pleno Mahkamah Konstitusi pada Kamis, 7 Desember 2006 
Zahratul Ain Taufik |Penyelesaian Kasus Pelanggaran Ham Berat Melalui Pola Rekonsiliasi Pasca Putusan.....

Jurnal/Artikel/Makalaj/Laporan Penelitian/Web

Agus Raharjo, Implikasi Pembatalan Undang-Undang Komisi Kebenaran Dan Rekonsiliasi Terhadap Prospek Penanganan Pelanggaran Berat Hak Asasi Manusia, Jurnal Mimbar Hukum. Vol. 19, No 1 (Februari 2007

Barda Nawawi Arief, Mediasi Pidana (Penal Mediation) Dalam Penyelesaian Sengketa/Masalah Perbankan Beraspek Pidana Di Luar Pengadilan, bahan presentasi pada Dialog Interaktif Mediasi Perbankan, di Bank Indonesia Semarang, 13 Desember 2006

Basniwati, A. D. "THE POSITION AND AUTHORITY OF CONSTITUTIONAL COURT IN CONSTITUTIONAL SYSTEM OF THE REPUBLIC OF INDONESIA." Jurnal IUS (Kajian Hukum dan Keadilan) 2.2 (2014).

Elsam, Mendorong Pembentukan Kembali UU Komisi Kebenaran dan Rekonsiliasi, Laporan terkait Pandangan ELSAM Mengenai Pentingnya RUU Komisi Kebenaran dan Rekonsiliasi, tahun tidak disebutkan

http://elsam.or.id/downloads/248204_ $\mathrm{H}$ a si $1_{-} \mathrm{P}$ e n y e $1 \mathrm{id}$ i ka n Komnas_HAM_yang_Belum_ Ditindaklanjuti. pdf, diakses pada 10 april 2014, 23.08

Elsam, Praktik Terbaik dari Palu untuk Penyelesaian Pelanggaran HAM Masa Lalu, Dalam http://elsam. or.id/2016/03/praktik-terbaikdari-palu-untuk-penyelesaianpelanggaran-ham-masa-lalu, diakses pada Rabu 29 Maret 2017 pukul 12:11 wita

Ibnu Artadi, Dekonstruksi Pemahaman Penyelesaian Sengketa Bisnis
(Ekonomi dan Keuangan) Beraspek Pidana Melalui Prosedur Perdamaian -Menuju Proses Peradilan Pidana Rekonsiliatif-, Jurnal Hukum Responsif, Vol 1 (tahun tidak disebutkan)

Komnas HAM, Upaya Negara Menjamin Hak-Hak Kelompok Minoritas di Indoneisia, Laporan, 2016

Kontras, Memahami Komisi Kebenaran dan Rekonsiliasi, selebaran (leaflet), diolah dari berbagai sumber untuk disosialisasikan kepada korban pelanggaran HAM berat di Aceh perihal Komisi Kebenaran dan Rekonsiliasi, Tahun tidak disebutkan

Kuat Puji Prayitno, Restorative Justice untuk Peradilan di Indonesia (Prespektif Yuridis Filosofis dalam Penegakan Hukum In ConCreto), Jurnal Dinamika Hukum, Vol. 12, No. 3, (September 2012).

Muh Risnain dan Sri Karyati, Menimbang Gagasan Perubahan Konstitusi dan Tata Cara Perubahan Konstitusi Republik Indonesia 1945, Jurnal Ius Volume 5 No. 1 2017, hlm 115.

Nota Kesepahaman antara Pemerintah Republik Indonesia dan Gerakan Aceh Merdeka, ditandatangani di Helsinki, Finlandia pada Senin 15 Agustus 2005

R. Herlambang P. Wiratraman, Akses Keadilan Bagi Korbann Pelanggaran HAM Pasca Putusan MK No. 006/PUU-IV/2006, Jurnal Recht Vinding, Vol. 2, No. 2, (Agustus 2013)

Rekonsiliasi sebagai tujuan, Versi Ramah Cetak, di akses melalui www.elsam. or.id

Sahuri Lasmadi, Mediasi Penal dalam Sistem Peradilan Pidana Indonesia, Makalah oleh Dosen Fakultas 
Hukum dan Program Pascasarjana Universitas Jambi, Tahun tidak disebutkan

Sandy Ari Wijaya, Prinsip Mediasi Penal Dalam Tindak Pidana KDRT, Jurnal IUS Prulalisme Hukum, 2014, Vol. 2 No. 6

Tim Penyusun Laporan Komnas Ham, Laporan Tahunan 2014, Komisi Nasional Hak Asasi Manusia Republik Indonesia, Jakarta, 2014

Wijaya, Sandy Ari. "PRINCIPLE MEDIATION OF DOMESTIC VIOLENCE AS CRIMINAL ACT." Jurnal IUS (Kajian Hukum dan Keadilan) 2.3 (2014).

Wijaya, I. Dewa Made Putra. "MEASURING THE DEMOCRATIZATION DEGREE ACCORDING TO LAW NUMBER 42 OF 2008 CONCERNING GENERAL ELECTION OF THE PRESIDENT AND VICE PRESIDENT." Jurnal IUS (Kajian Hukum dan Keadilan) 2.3 (2014). 